\title{
Analisis Kepuasan dan Loyalitas Pelanggan Telepon Seluler dengan Citra Perusahaan dan Ekuitas Merek sebagai Variabel Eksogen
}

\author{
Rully Armanto ${ }^{1)}$, Muji Gunarto ${ }^{2)^{*}}$ \\ 1)Universitas Taman Siswa \\ 2)Universitas Bina Darma \\ *)Email Koresponden: mgunarto@binadarma.ac.id
}

\begin{abstract}
The purpose of this study was to determine whether the satisfaction and loyalty of cellular phone customers is influenced by corporate image and brand equity. The sample of this research is student cell phone users in Palembang City, amounting to 250 respondents. The sampling technique used was cluster random sampling. The statistical analysis technique used Structural Equation Modeling (SEM) with the help of LISREL software. The results showed that consumer satisfaction of cell phone users was significantly influenced by brand equity, while consumer loyalty of cellular phone users was influenced by corporate image and satisfaction. These results also indicate that satisfaction is an intervening variable for the relationship between brand equity and consumer loyalty, meaning that consumer loyalty can be built with brand equity through customer satisfaction. Better brand equity will increase customer satisfaction which in turn will increase consumer loyalty.
\end{abstract}

Keywords: consumers loyalty, consumer satisfaction, brand equity, firm image

\begin{abstract}
Abstrak
Tujuan penelitian ini adalah untuk mengetahui apakah kepuasan dan loyalitas pelanggan telepon seluler dipengaruhi oleh citra perusahaan dan ekuitas merek. Sampel penelitian ini adalah mahasiswa pengguna telepon seluler di Kota Palembang yang berjumlah 250 responden. Teknik sampling yang digunakan adalah cluster random sampling. Teknik analisis statistik digunakan Structural Equation Modeling (SEM) dengan bantuan software LISREL. Hasil penelitian menunjukkan bahwa kepuasan konsumen pengguna telepon seluler secara signifikan dipengaruhi oleh ekuitas merek, sedangkan loyalitas konsumen pengguna telepon seluler dipengaruhi oleh citra perusahaan dan kepuasan. Hasil ini juga menunjukkan bahwa kepuasan menjadi variabel intervening bagi hubungan equitas merek denngan loyalitas konsumen, artinya bahwa loyalitas konsumen dapat dibangun dengan equitas merek melalui kepuasan konsumen. Equitas merek yang semakin baik akan meningkatkan kepuasan konsumen yang pada akhirnya akan meningkatkan loyalitas konsumen.
\end{abstract}

Kata Kunci: loyalitas konsumen, kepuasan konsumen, equitas merek, citra perusahaan.

\section{Pendahuluan}

Persaingan dunia usaha saat ini semakin ketat, sehingga mendorong perusahaanperusahaan untuk berlomba secara cepat dalam mendapatkan pangsa pasar. Pangsa pasar yang tinggi akan berpengaruh pada penjualan produknya. Dilihat dari sudut pandang merek dan pelanggan, maka tidak bisa lepas dari konsep ekuitas merek (brand equity) dan ekuitas pelanggan (customer equity). Secara konsep, ekuitas merek (brand equity) adalah seperangkat aset dan labilitas yang berkaitan dengan merek, nama dan simbolnya, yang dapat menambah atau mengurangi nilai yang diberikan oleh sebuah barang atau jasa kepada perusahaan atau para pelanggan perusahaan (Kotler \& Armstrong, 2016). Adapun menurut (D.A. Aaker, 1998), brand equity dapat dikelompokkan kedalam lima kategori yaitu loyalitas merek (brand loyalty), kesadaran merek (brand awareness), kesan kualitas 
(perceived quality), asosiasi merek (brandassociation) dan aset-aset merek lainnya seperti paten, cap, dan lain-lain.

Ekuitas merek adalah nilai tambah (incremental utility) suatu produk yang diberikan melalui nama mereknya seperti Nokia, Coke, Kodak, Levi's dan Nike (Farquhar, Han, dan Ijiri, 1991 dalam Yoo et al., 2000; Kamakura dan Russel, 1993; Park dan Srinivasan, 1994; Rangaswarmy, Burke dan Oliva, 1993). Para peneliti menduga bahwa ekuitas merek bisa diukur dengan mengurangi utilitas atribut fisik produk dari total utilitas suatu merek. Sebagai aset yang penting bagi perusahaan, ekuitas merek bisa meningkatkan cash flow bagi bisnis (Simon dan Sullivan, 1993). Dari sisi perilaku, ekuitas merek penting untuk memberikan diferensiasi yang mampu menciptakan keunggulan kompetitif berdasarkan persaingan non harga (David A. Aaker, 1989).

Perilaku konsumen terhadap produk telepon seluler disamping terpengaruh karena merek, juga karena citra perusahaan yang memproduksinya dianggap baik. Perasaan puas atau tidaknya konsumen terjadi setelah mempunyai pengalaman dengan produk maupun perusahaan yang diawali adanya keputusan pembelian. Sehingga dapat disimpulkan keberadaan citra perusahaan yang baik penting sebagai sumber daya internal obyek dalam menentukan hubungannya dengan perusahaan.

Berdasarkan latar belakang permasalahan di atas, maka penulis tertarik untuk melakukan penelitian lebih lanjut tentang pengaruh ekuitas merek dan citra perusahaan terhadap hubungan antara kepuasan konsumen dengan loyalitas pelanggan telepon seluler. Sesuai dengan latar belakang, maka yang menjadi permasalahan dalam penelitian ini adalah: (1) Seberapa besar pengaruh langsung ekuitas merek dan citra perusahaan terhadap loyalitas pelanggan telepon seluler? (2) Seberapa besar pengaruh tidak langsung ekuitas merek dan citra perusahaan terhadap loyalitas pelanggan telepon seluler dengan kepuasan konsumen sebagai variabel intervening?

\section{Tinjauan Pustaka}

\subsection{Ekuitas Merk (Brand Equity)}

Istilah Ekuitas Merk (brand equity) adalah seperangkat aset dan labilitas merek yang terkait dengan nama dan simbol sebuah merk, yang mampu menambah atau mengurangi nilai yang diberikan oleh suatu produk atau jasa kepada perusahaan maupun kepada pelanggan perusahaan (Aaker, 1997).

Aset adalah sesuatu yang dimiliki sebuah perusahaan, seperti merek atau lokasi penjualan eceran, yang membuatnya unggul dalam kompetisi. Keahlian (liabilitas) adalah sesuatu yang dilakukan sebuah perusahaan dengan lebih baik dibandingkan para kompetitornya, seperti periklanan atau proses manufaktur yang efisien. Agar aset dan liabilitas mendasari ekuitas merek (brand equity), keduanya harus berhubungan dengan nama atau simbol sebuah merek. Aset dan liabilitas yang menjadi dasar ekuitas merek akan berbeda antara satu konteks dengan konteks lainnya. Keduanya bisa dikelompokkan dalam 5 kategori (Aaker, 1997), yaitu:

1. Kesadaran merek (brand awareness)

2. Asosiasi merek (Brand association)

3. Kesan kualitas (Perceived quality) 
4. Loyalitas merek (Brand loyalty)

5. Aset-aset merek lainnya seperti paten, cap, dan lain-lain.

\subsection{Citra Perusahaan}

Menurut Kotler (2005), "Citra adalah seperangkat keyakinan, ide, dan kesan yang dimiliki seseorang terhadap suatu obyek". Sutisna (2001) mengemukakan bahwa, "Citra adalah total persepsi terhadap suatu obyek yang dibentuk dengan memproses informasi dari berbagai sumber setiap waktu". Menurut Alma (2005), citra tidak dapat dicetak seperti membuat barang di pabrik, akan tetapi citra adalah kesan yang diperoleh sesuai dengan pengetahuan dan pemahaman seseorang tentang sesuatu. Citra terbentuk dari bagaimana perusahaan melaksanakan kegiatan operasionalnya, yang mempunyai landasan utama pada segi layanan. Definisi citra menurut Kasali (2003) yaitu, "Kesan yang timbul karena pemahaman akan suatu kenyataan". Berdasarkan pendapat-pendapat tersebut, citra menunjukan kesan suatu obyek terhadap obyek lain yang terbentuk dengan memproses informasi setiap waktu dari berbagai sumber terpercaya. Terdapat tiga hal penting dalam citra, yaitu: kesan obyek, proses terbentuknya citra, dan sumber terpercaya. Obyek meliputi individu maupun perusahaan yang terdiri dari sekelompok orang di dalamnya. Citra dapat terbentuk dengan memproses informasi yang tidak menutup kemungkinan terjadinya perubahan citra pada obyek dari adanya penerimaan informasi setiap waktu. Besarnya kepercayaan obyek terhadap sumber informasi memberikan dasar penerimaan atau penolakan informasi. Sumber informasi dapat berasal dari perusahaan secara langsung dan atau pihak-pihak lain secara tidak langsung.

Menurut Harrison (1995) informasi yang lengkap mengenai citra perusahaan meliputi empat elemen sebagai berikut:

\section{Personality}

Keseluruhan karakteristik perusahaan yang dipahami publik sasaran seperti perusahaan yang dapat dipercaya, perusahaan yang mempunyai tanggung jawab sosial.

\section{Reputation}

Hal yang telah dilakukan perusahaan dan diyakini publik sasaran berdasarkan pengalaman sendiri maupun pihak lain seperti kinerja keamanan transaksi di bank.

\section{Value}

Nilai-nilai yang dimiliki suatu perusahan dengan kata lain budaya perusahaan seperti sikap manajemen yang peduli terhadap pelanggan, karyawan yang cepat tanggap terhadap permintaan maupun keluhan pelanggan.

\section{Corporate Identity}

Komponen-komponen yang mempermudah pengenalan publik sasaran terhadap perusahaan seperti logo, warna, dan slogan.

\subsection{Kepuasan Konsumen}

Menurut Tjiptono (2000) kepuasan atau ketidakpuasan pelanggan adalah respon pelanggan terhadap evolusi ketidaksesuaian yang dirasakan antara harapan sebelumnya dan kinerja aktual produk yang dirasakan bahwa pada persaingan yang semakin ketat ini, 
semakin banyak produsen yang terlibat dalam pemenuhan kebutuhan dan keinginan konsumen sehingga hal ini menyebabkan setiap badan usaha harus menempatkan orientasi pada kepuasan pelanggan sebagai tujuan utama, antara lain dengan semakin banyaknya badan usaha yang menyatakan komitmen terhadap kepuasan pelanggan dalam pernyataan misi iklan.

Menurut Kotler (2005) konsumen yang terpuaskan sebagai pelanggan akan: 1) Melakukan pembelian ulang; 2) Mengatakan hal-hal yang baik tentang perusahaan kepada orang lain; 3) Kurang memperhatikan merek ataupun iklan produk pesaing; dan 4) Membeli produk yang lain dari perusahan yang sama.

\subsection{Loyalitas Pelanggan}

Menurut Olson (1993), loyalitas pelanggan merupakan dorongan perilaku untuk melakukan pembelian secara berulang-ulang dan untuk membangun kesetiaan pelanggan terhadap suatu produk/jasa yang dihasilkan oleh badan usaha tersebut membutuhkan waktu yang lama melalui suatu proses pembelian yang berulang-ulang tersebut.

Selanjutnya Griffin (2003) berpendapat bahwa seseorang pelanggan dikatakan setia atau loyal apabila pelanggan tersebut menunjukkan perilaku pembelian secara teratur atau terdapat suatu kondisi dimana mewajibkan pelanggan membeli paling sedikit dua kali dalam selang waktu tertentu. Upaya memberikan kepuasan pelanggan dilakukan untuk mempengaruhi sikap pelanggan, sedangkan konsep loyalitas pelanggan lebih berkaitan dengan perilaku pelanggan daripada sikap dari pelanggan.

Smith (1970) memperkirakan bahwa konsumen secara umum terbagi menjadi 4 kelompok, tergantung dari bagaimana mereka berbelanja. Salah satu model yang paling relevan dalam mengukur loyalitas konsumen menurut Oliver (1999), yaitu four stage loyalty model.

Pendapat Griffin, Smith, dan Oliver di atas memberikan dimensi yang lebih luas tentang ukuran perilaku pelanggan yang loyal. Pertama, loyalitas pelanggan diukur dari jumlah rata-rata pembeli produk pelumas tertentu dalam jangka waktu tertentu. Pelanggan yang rata-rata penggunaan produk pelumas tertentu lebih tinggi berarti dapat dikatakan lebih loyal dari pelanggan yang rata-rata penggunaannya lebih rendah. Kedua, ukuran loyalitas pelanggan berkembang pada perilaku pembelian pelanggan terhadap layanan baru yang dikeluarkan oleh suatu produk bila pelanggan tersebut tidak beralih menjadi pelanggan pelumas lain, pelanggan akan tetap loyal kepada produk tersebut dalam menggunakan pelumas mobilnya. Ukuran ketiga loyalitas pelanggan adalah sikap dari pada pelanggan dalam memberikan rekomendasi bagi orang lain untuk menggunakan produk pelumas mobil. Pelanggan yang loyal akan memberikan rekomendasi bagi orang lain untuk menggunakan produk pelumas tersebut.

Hubungan antar variabel dalam penelitian disajikan dalam kerangka berfikir seperti pada Gambar 1. 


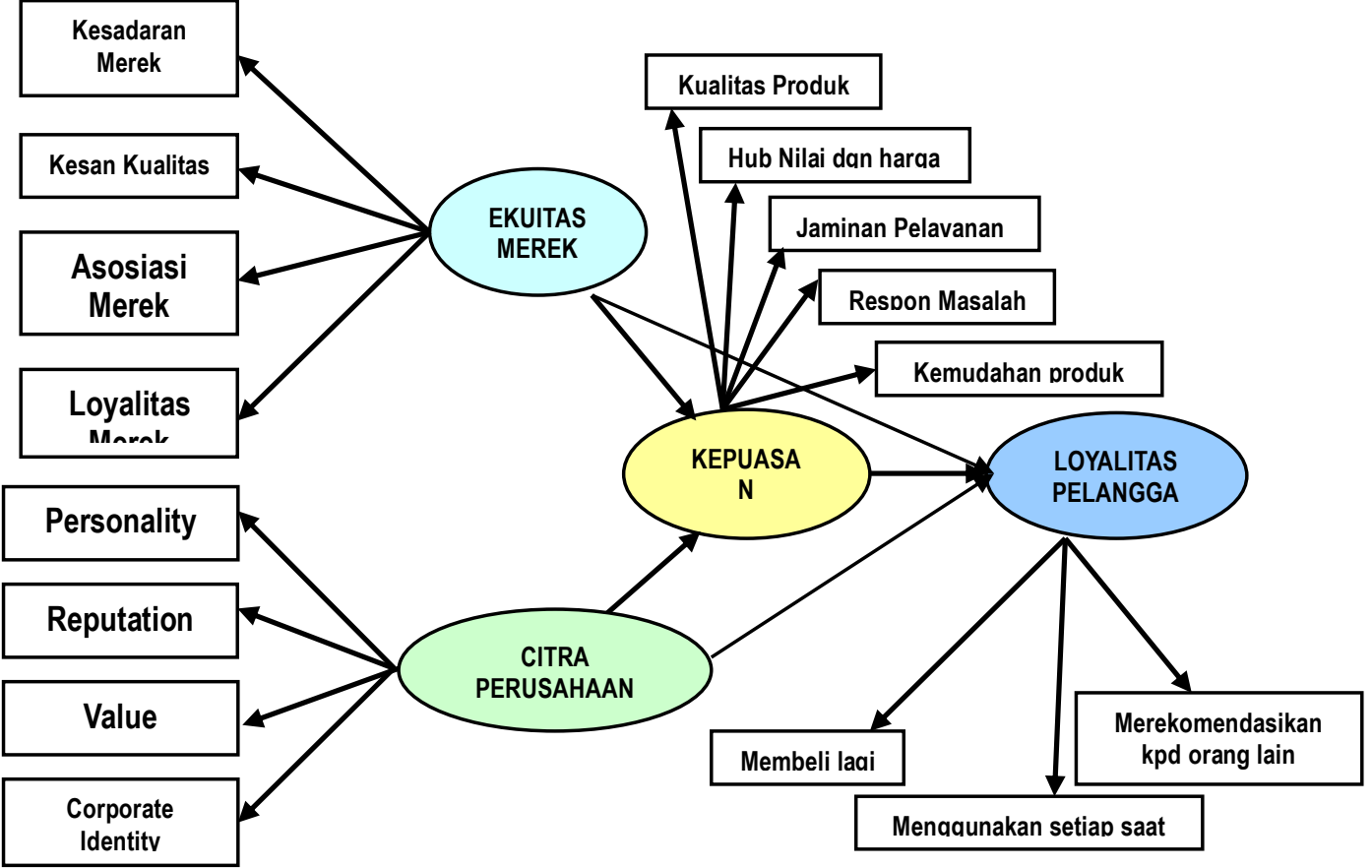

Gambar 1. Kerangka Berfikir

\subsection{Hipotesis Penelitian}

Hipotesis dalam penelitian ini dapat dirumuskan sebagai berikut:

1. Ekuitas merek (Brand Equity) berpengaruh signifikan terhadap kepuasan konsumen (customer satisfaction).

2. Citra perusahaan (corporate image) berpengaruh signifikan terhadap kepuasan konsumen (customer satisfaction).

3. Ekuitas merek (Brand Equity) dan Citra perusahaan (corporate image) berpengaruh signifikan terhadap kepuasan konsumen (customer satisfaction).

4. Kepuasan konsumen (customer satisfaction) berpengaruh signifikan terhadap loyalitas pelanggan (customer loyalty).

\section{Metode Penelitian}

\subsection{Desain Penelitian}

Desain penelitian ini adalah deskriptif asosiatif. Penelitian deskriptif bertujuan untuk memperoleh secara jelas tentang suatu situasi atau keadaan tertentu, sedangkan penelitian asosiatif bertujuan untuk mengetahui hubungan suatu variabel bebas dengan variabel terikat (menguji hipotesis) melalui pengumpulan data di lapangan. Metode penelitian yang digunakan adalah metode survei yaitu penelitian ini mengambil sampel dari populasi dengan menggunakan kuesioner sebagai alat pengumpulan data utamanya.

\subsection{Populasi dan Sampel}

Populasi penelitian ini adalah konsumen yang menggunakan merek telepon seluler (HP). Populasi penelitian ini dibatasi pada pengguna telepon seluler yang ada di Kota Palembang. 
Metode sampel dalam penelitian ini menggunakan teknik pengambilan sampel area (area sampling design) yaitu bentuk pengambilan sampel cluster dalam suatu area. Menurut Sekaran (2006) pengambilan sampel area merupakan cluster geografis, yaitu pemilihan sampel setelah dilakukan pembagian populasi ke dalam beberapa cluster, kemudian mengambil sampel secara acak (random) dari cluster - cluster tersebut sebagai subjek atau responden. Jumlah sampel untuk pre-test closed ended questionnaire adalah 20 responden dan sampel penelitian sebanyak 250 orang responden.

\subsection{Teknik Pengumpulan Data}

Teknik pengumpulan data yang dilakukan dalam penelitian ini adalah dengan menggunakan cara studi lapangan (field research) yaitu dengan melakukan observasi dan penyebaran kuesioner yang telah dipersiapkan.

\subsection{Teknik Analisis Data}

Teknik analisis statistik yang digunakan dalam penelitian ini adalah pendekatan model persamaan struktural (Structural Equation Model - SEM). Structural Equation Model (SEM), merupakan suatu teknik modeling statistika yang paling umum dan telah digunakan secara luas dalam ilmu perilaku (behavior science). SEM dapat ditunjukkan sebagai kombinasi dari analisis faktor, analisis regresi, dan analisis path (Hair et al., 2006). Proses pengolahan data dilakukan dengan bantuan paket program Microsoft Office Excel 2003, Program SPSS for Windows versi 15, dan Program LISREL Versi 8.50

\section{Hasil dan Pembahasan}

Hasil analisis dan pembahasan dapat dijelaskan sebagai berikut.

1. Analisis Faktor Confirmatori dan Analisis Reliabilitas

Hasil analisis faktor konfirmatori dan reliabilitas masing-masing variabel laten terlihat seperti pada Tabel 4.12. di bawah.

Tabel 1. Hasil Analisis Faktor Confirmatori dan Reliabilitas Variabel Laten

\begin{tabular}{|c|c|c|c|c|}
\hline Indikator & EM & CP & KK & LP \\
\hline EM1 & 0.49 & & & \\
\hline EM2 & 0.62 & & & \\
\hline EM3 & 0.61 & & & \\
\hline EM4 & 0.65 & & & \\
\hline CP1 & & 0.59 & & \\
\hline CP2 & & 0.63 & & \\
\hline CP3 & & 0.66 & & \\
\hline CP4 & & 0.81 & & \\
\hline
\end{tabular}




\begin{tabular}{|c|c|c|c|c|}
\hline KK1 & & & 0.70 & \\
\hline KK2 & & & 0.80 & \\
\hline KK3 & & & 0.62 & \\
\hline KK4 & & & 0.76 & \\
\hline KK5 & & & & 0.88 \\
\hline LP1 & & & & 0.59 \\
\hline LP2 & & & & 0.75 \\
\hline LP3 & & 0.888 & 0.864 & 0.907 \\
\hline Reliabilitas & 0.877 & & & \\
\hline
\end{tabular}

Berdasarkan Tabel 1. terlihat bahwa faktor loading masing-masing konstruk terhadap variabel laten yang dibentuknya semuanya valid karena lebih besar dari 0,3. Hasil analisis reliabilitas terhadap masing-masing variabel laten juga menunjukkan reliabel, karena diperoleh nilai reliabilitas yang lebih besar dari 0,5. Dengan demikian semua indikator tersebut layak dijadikan sebagai pembentuk variabel-variabel laten tersebut.

\section{Struktural Equation Models (SEM)}

Persamaan model struktural dalam penelitian ini dilakukan untuk membuktikan hipotesis yang telah diungkapkan pada bab sebelumnya. Dengan bantuan paket program Lisrel 8.50 diperoleh diagram hasil analisis SEM seperti pada Gambar 2.

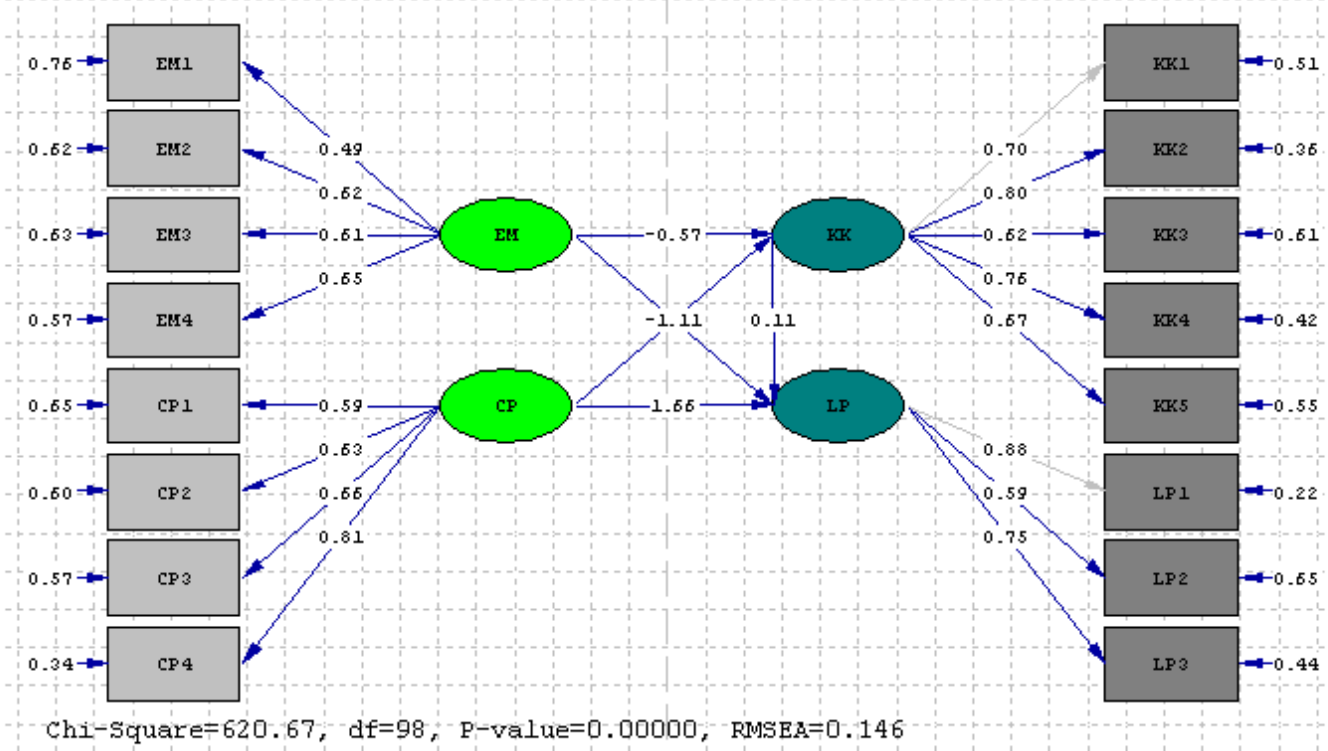

Gambar 2. Diagram Hubungan Antar Variabel dan Nilai-nilai Parameternya 
Gambar 2 menunjukkan hubungan antara indikator terhadap masing-masing variabel laten dan hubungan antara variabel eksogen dengan variabel endogen, maupun antara variabel endogen dengan variabel endogen. Pada penelitian ini ada dua variabel eksogen, yaitu Ekuitas Merek (EM) dan Citra Perusahaan (CP). Ada dua variabel endogen, yaitu Kepuasan Konsumen (KK) dan Loyalitas Pelanggan (LP).

Ringkasan hasil-hasil pendugaan parameter dengan analisis SEM dapat dilihat seperti pada Tabel 3.

Tabel 3. Ringkasan Hasil Analisis SEM

\begin{tabular}{|c|c|c|c|c|}
\hline Hubungan & $\begin{array}{l}\text { Parameter } \\
\text { Pengaruh } \\
\text { Langsung }\end{array}$ & Standar Error & T-Hitung $(>1,96)$ & $\mathrm{R}^{2}$ \\
\hline EM-KK & -0.57 & 0.33 & -1.74 & \multirow{2}{*}{0.76} \\
\hline CP-KK & 1.26 & 0.33 & $3.79 *$ & \\
\hline EM-LP & -1.11 & 0.56 & $-1.97^{*}$ & \multirow{3}{*}{0.97} \\
\hline CP-LP & 1.66 & 0.74 & $2.23 *$ & \\
\hline KK-LP & 0.11 & 0.29 & 0.36 & \\
\hline \multicolumn{5}{|c|}{ Goodness of Fit Statsitics } \\
\hline \multicolumn{3}{|l|}{ Chi-Square } & $=620.67$ & \\
\hline \multicolumn{3}{|c|}{ Degrees of Freedom } & $=98$ & \\
\hline \multicolumn{3}{|c|}{ Root Mean Square Error of Approximation (RMSEA) } & A) $=0.146$ & Baik \\
\hline \multicolumn{3}{|c|}{ Goodness of Fit Index (GFI) } & $=0.76$ & Cukup baik \\
\hline \multicolumn{3}{|c|}{ Adjusted Goodness of Fit Index (AGFI) } & $=0.67$ & Baik \\
\hline \multicolumn{3}{|c|}{ Root Mean Square Residual (RMR) } & $=0.086$ & Baik \\
\hline
\end{tabular}

Hasil analisis dengan SEM pada model (1) menunjukkan bahwa Ekuitas Merek berpengaruh negatif tetapi tidak signifikan terhadap kepuasan konsumen, sedangkan Citra perusahaan berpengaruh positif dan signifikan terhadap Kepuasan konsumen. Hasil ini sejalan dengan penelitian Gunarto dan Septayuda (2016).

Hasil analisis dengan SEM pada model (2) menunjukkan bahwa Ekuitas Merek berpengaruh negatif dan signifikan terhadap Loyalitas pelanggan dan Citra perusahaan berpengaruh positif dan signifikan terhadap Loyalitas pelanggan yang sejalan dengan penelitian (Gunarto dkk, 2018a; Gunarto dkk, 2018b; Harahap dkk, 2020), namun Kepuasan konsumen tidak berpengaruh signifikan terhadap Loyalitas pelanggan. Hasil ini tidak sejalan dengan temuan Gunarto (2009) dan Gunarto dan Hurriyati (2020). 


\section{Kesimpulan dan Saran}

\subsection{Kesimpulan}

Kesimpulan dari penelitian ini adalah sebagai berikut:

1. Besarnya pengaruh Ekuitas Merek terhadap kepuasan konsumen sebesar $-0,57$ dengan nilai t-hitung sebesar -1,74. Hal ini menunjukkan bahwa ekuitas merek berpengaruh negatif tetapi tidak signifikan terhadap kepuasan konsumen. Besarnya pengaruh Ekuitas Merek terhadap loyalitas pelanggan sebesar -1,11 dengan nilai thitung sebesar $-1,97$. Hal ini menunjukkan bahwa ekuitas merek berpengaruh negatif baik terhadap kepuasan konsumen maupuan loyalitas pelanggan, namun tidak signifikan terhadap kepuasan konsumen.

2. Besarnya pengaruh Citra perusahaan terhadap kepuasan konsumen sebesar 1,26 dengan nilai t-hitung sebesar 3,79. Hal ini menunjukkan bahwa Citra perusahaan berpengaruh negatif dan signifikan secara langsung terhadap kepuasan konsumen. Besarnya pengaruh Citra perusahaan terhadap loyalitas pelanggan sebesar 1,66 dengan nilai t-hitung sebesar 2,23. Hal ini menunjukkan bahwa Citra perusahaan berpengaruh positif dan signifikan secara langsung terhadap Kepuasan konsumen dan loyalitas pelanggan.

3. Kepuasan konsumen bukan merupakan variabel intervening bagi Ekuitas Merek dan Citra perusahaan terhadap Loyalitas pelanggan, karena kepuasan konsumen tidak berpengaruh signifikan terhadap loyalitas pelanggan. Hal ini terlihat dari nilai parameter sebesar 0,11 dengan t-hitung sebesar 0,36 yang jauh lebih kecil dari 1,96. Artinya bahwa secara statistik berpengaruh positif tetapi pengaruhnya sangat kecil dan tidak signifikan.

\subsection{Saran-Saran}

Berdasarkan kesimpulan di atas, maka penulis menyarankan hal-hal sebagai berikut:

1. Untuk dapat meningkatkan loyalitas pelanggan khususnya telepon seluler perlu menjaga ekuitas mereknya dan melakukan tindakan-tindakan untuk meningkatkan citra perusahaan, seperti mencari merek yang mudah diingat, menjaga kualitas pelayanan dan produk, serta perusahaannya memiliki tanggung jawab sosial.

2. Untuk peneliti yang akan datang, disarankan untuk mencoba mencari faktor-faktor lain yang kiranya dapat berpengaruh terhadap loyalitas pelanggan seperti: komunikasi, kepercayaan pelanggan, persepsi terhadap kualitas, dan kualitas pelayanan, sehingga dapat ditemukan model yang baku untuk loyalitas pelanggan.

\section{Referensi}

Aaker, David A. 1997. Manajemen Ekuitas Merek Memanfaatkan Nilai dari Suatu Merek. (alih bahasa Aris Ananda). Cetakan Pertama. Jakarta: Penerbit Spektrum Mitra Utama.

Alma, Buchari. 2005. Manajemen Pemasaran dan Pemasaran Jasa. Bandung: Alfabeta.

Andreassen, Tor Wallin and Bodil Lindestad. 1998. The Impact of Corporate Image on Quality, customer Satisfaction and Loyalty for Customers with Varying degrees of Service Expertise. International Journal of Service Industry Management vol.9 No.1: 723. 
Assael, Henry. 1992. Consumer Behavior and Marketing Action. Boston: PWSKENT Publishing Company.

Dharmmesta, B. S. 1998, "Theory of Planned Behaviour dalam penelitian sikap, niat dan perilaku konsumen," Kelola, No.18/VII, 85-103.

1999,"Loyalitas Pelanggan: Sebuah Kajian Konseptual Sebagai Panduan Bagi Peneliti," Journal Ekonomi dan Bisnis Indonesia, Vol.14, N0.3, 73-88

Durianto, Darmadi; Sugiarto dan Tony Sitinjak. 2004. Strategi Menaklukkan Pasar Melalui Riset Ekuitas dan Perilaku Merek. Cetakan Ketiga. Jakarta: PT. Gramedia Pustaka Umum.

Fishbein, M., and I. Ajzen 1975, Belief, Attitude, Intention and Behavior: An Introduction to Theory and Research, Addison-Wesley Publishing Company, Reading, Massachusetts.

Griffin, J. 2003, Customer Loyalty: Menumbuhkan \& Mempertahankan Kesetiaan Pelanggan, Alih Bahasa: Dr. Dwei Kartini Yahya, Penerbit Erlangga, Jakarta.

Gunarto, M. (2009). Pengaruh Bauran Promosi terhadap Citra Perusahaan dan Kepuasan Konsumen serta Implikasinya terhadap Loyalitas Pelanggan Minyak Pelumas Mobil di Kota Palembang. Kaji. Ekon. J. Penelit. Bid. Ekon, 8(1), 1-16.

Gunarto, M., \& Septayuda, I. (2016). Analisis Ekuitas Merek dalam Persaingan Perguruan Tinggi Swasta di Kota Palembang. Jurnal ilmiah MBiA, 15(2).

Gunarto, M., Hurriyati, R., Disman, \& Wibowo, L. A. (2018a). Building students' loyalty in private higher education institutions: activities for competitiveness. International Journal of Education Economics and Development, 9(4), 394-410.

Gunarto, M., Hurriyati, R., Disman, \& Wibowo, L. A. (2018b). Building students' loyalty in private higher education institutions: activities for competitiveness. International Journal of Education Economics and Development, 9(4), 394-410.

Gunarto, M., \& Hurriyati, R. (2020). Creating Experience value to build student satisfaction in higher education. arXiv preprint arXiv:2006.09846.

Harahap, D. A., Amanah, D., Gunarto, M., Purwanto, P., \& Umam, K. (2020). Pentingnya citra universitas dalam memilih studi di perguruan tinggi. NIAGAWAN, 9(3), 191-196.

Kartajaya, Hermawan. 2003. MarkPlus on Strategy. PT. Gramedia Pustaka Utama, Jakarta.

Kasali, Rhenald. 2003. Manajemen Public Relations; Konsep dan Aplikasinya di Indonesia. PT. Pustaka Utama Grafiti: Jakarta.

Keller, Levin Lane (2003). Strategic Brand Management: Building, Measuring, and Managing Brand Equity, Second Edition. Upper Saddle River, New Jersey. Pearson Education, Inc.

Kotler, Philip dan Gary Amstrong, 1997. Dasar-dasar Pemasaran (Principle of Marketing 7e), Jilid I dan II, Penerbit Prenhallindo, Jakarta.

Kotler, Philip, 2005. Manajemen Pemasaran (Principle of Marketing 9e). Analisis Perencanaan, Implementasi dan Kontrol, Jilid I dan II, Penerbit Prenhallindo, Jakarta. 
Kurt, David L and Kenneth Clow.1998. Service Marketing. Singapore. John Wiley \& Sons, Inc.

Loudon, David L and Della Bitta, Albert L. 1993. Consumer Behaviour: Concepts and Application. (Fourth Edition). Singapore.

Majalah Marketing No. 02/IX/Februari 2009.

Netemeyer, R.G., et al, 2004, Developing and validating measures of facets of customerbased brand equity, Journal of Business Research, VOL. 57 (August), p. $209-224$.

Nguyen, N. And Leblanc, G. 2001. The Mediating Role Of Corporate Image On Customers' Retention Decisions: An Investigating In Financial Service. The International Journal of Marketing, Bradford. Vol 16, pp 52.

Okidarsyah, Muhammad. 2008. "Pengaruh Kualitas Pelayanan, Citra Perusahaan, Switching Barrier, dan Kepuasn Pelanggan terhadap Loyalitas Pelanggan (Studi Kasus di Perusahaan Asuransi Kerugian)." Makalah Prosiding Seminar Nasional Manajemen Teknologi VIII, Program Studi MMT-ITS, Surabaya 2 Agustus 2008.

Oliver, R.L. 1997. Satisfaction A Behavioral Perspective on The Consumer. United States ofAmerica: The Mc Graw-Hill Companies, Inc.

Olson, Peter, 1993, Consumer Behavior and Marketing Strategy, Richard D. Irwan Inc, Boston, Third Edition.

Peter, J. P., and J. C. Olson. 2002. Consumer Behavior and Marketing Strategy, McGrawHill International Editions, Boston.

Puspowarsito, HAH., 2008, Metode Penelitian Organisasi dengan Aplikasi Program SPSS, Penerbit Humaniora, Bandung.

Rangkuti, Freddy., 2002. The Power of Brands, PT. Gramedia Pustaka Utama, Jakarta.

Reichheld, F., and P. Schefter. 2000,"E-Loyalty: Your Secret Weapon on the Web," Harvard Business Review, July-August, 105-113.

Sekaran, Uma. 2006, Research Methods For Business, John Wiley \& Sons, Inc.

Semuel, Hatane. 2006. "Ekspektasi Pelanggan Dan Aplikasi Bauran Pemasaran Terhadap Loyalitas Toko Moderen Dengan Kepuasan Pelanggan Sebagai Intervening (Studi Kasus pada Hypermarket Carrefour di Surabaya)," Jurnal Manajemen Pemasaran, Vol. 1, No. 2, Oktober 2006: 53-64.

Simamora, Bilson. 2004. Panduan Riset Perilaku Konsumen. Cetakan Kedua. Jakarta: PT. Gramedia Pustaka Umum

Simon, Carol J and Mary W.Sullivan. (1993) The Measurement and Determinants of Brand Equity: A Financial Approach. Marketing Science 12 Winter.

Smith, S.A., 1970. How do Consumer Chooses Between Brands of Durable Goods? Journal of Retailing. Vol 46, No. 2, p. 18-265.

Soehadi, A.W. 2005. Effective branding: Konsep dan Aplikasi pengembangan merek yang sehat dan kuat. Bandung: Quantum Bisnis \& Manajemen.

Stanton, William J. 1995. Marketing Principles, terjemahan Y. Lamarto, Erlangga, 
Jakarta.

Sutisna. 2001. Perilaku Konsumen dan Komunikasi Pemasaran. Penerbit PT Remaja Rosdakarya. Bandung.

Tim Penyusun, 2004. Pedoman Umum Format Penulisan Tesis/Disertasi Program Pascasarjana Universitas Sriwijaya. Program Pascasarjana UNSRI, Palembang.

Tjiptono, Fandy, 2000. Strategi Pemasaran, Penerbit ANDI, Yogyakarta.

Widarjono, Agus, 2010.Analisis Statistik Multivariat Terapan. UPP STIM YKPN. Yogyakarta. 